\title{
The I mpact of Deregulation and Liberalization in the Nigerian Air Transport Industry: An Overview
}

\author{
Adeniyi Olufemi Oluwakoya CMILT ${ }^{1, a, *}$ \\ ${ }^{1}$ Department of Transport and Tourism Studies, Redeemer's University, Redemption City, \\ Ogun-state, Nigeria
}

\begin{abstract}
The effect of globalization is fast showing its attendant effects on the Nigerian aviation industry leading to an increase in passengers' traffic movement in Nigeria's airports. More importantly, there seems to be a paradigm shift which affects ownership and administration of operation in the Nigerian aviation industry. This study examines among others the impact of deregulation and liberalization in the Nigerian air transport industry; the effects of the latter on operation and control changes that affect operational efficiency in the airline business; and the impacts of liberalization on attracting foreign direct investment and foreign airline participation in the Nigerian aviation industry. The methodology used for this study is documentary research, which entails search of existing published and unpublished documents and databases of stakeholders in the Nigerian aviation industry and external sources with affinity to the sector. The results of this study reveal that an unprecedented growth has been recorded in Nigeria. It includes among others: healthy competition needed for growth and development; increased participation in the industry by foreign airlines; increased foreign direct investment in the airline business and airport infrastructure development.
\end{abstract}

Keywords: Deregulation, Globalization, Foreign Direct Investment, Nigerian Air Transport, Infrastructure, Economic Growth

\footnotetext{
a Mr Adeniyi Olufemi Oluwakoya is a seasoned transport and tourism professional with experience in the public sector before veering into academics. Presently, he is a Lecturer in the Department of Transport and Tourism studies, Redeemer's University, Mowe, Ogun-State, Nigeria.

*Tel: +2348055381535, E-mail:adeniyilove@yahoo.com,adeniyioluwakoya@gmail.com.
} 


\section{I NTRODUCTION}

Globalization impacts are fast revealing their significance in all fabrics of developing economies. The Nigerian air transport, no doubt benefited from the global economic new order of business transaction and promotion. Globalization brought complex network involving flows of information, commodities, parts and finished goods have been set, which in turn demands a high level of command of logistics and freight distribution (Rodrigue et al, 2006). According to Janelle and Beuthe (1997:199), 'In its simplest form, globalization refers to the increasing geographical scale of economic, social and political interactions. These include the expanding mobility of capital and investment transactions and the growth of tourism, global conferences and sporting event'.

Also, the major dividends of globalization reflect more a new paradigm of economic intervention to consolidate the globalist idea. The Nigerian aviation sector is a beneficiary of the retooling of the global economic structure. Its impact on the aviation sector is enormous. The benefits range from increased passenger traffic to, inter alia, foreign direct investment, institution development and airport development etc.

Furthermore, globalization is anticipated to cause substantial increase in international passengers and freight movements and low cost communication. Transport networks have suddenly became a veritable instrument in the global manufacturing and marketing enterprise (Adeniji, 2000). Nigeria can take advantage of the opportunities to upturn the woes of its economy.

The cumulative effect of globalization, liberalization, deregulation and privatization of air transport in Africa, and specifically Nigeria, was initiated in 1988 under the Yamoussoukro Declaration. This declaration called for the liberalization and integration of air services to pave the way for the African Continent to actively participate in the globalization process and regional development.

Similarly, Janelle and Beuthe (1997) point to the spatial implications of globalization for tourism and the transport link that relates to improved accessibility for tourism economies. In this light, its impact resulting from deregulation, liberalization of critical sector such aviation sector in a developing economy is needful. The deregulation of the air transportation in Nigeria has brought gains. Therefore, such impacts need to be stressed 
and examined. In this light this paper examined the impacts of deregulation in the Nigerian air transport sector. The methodology employed for writing this paper is documentary searches, which entails search of existing published and unpublished document and databases of stakeholders in the Nigerian aviation industry, and external sources in affinity with the sector.

This paper is divided into five sections. Section one is the introduction, and section two deals with the aviation industry in Nigeria. Section three examines air transport deregulation impact on economic, infrastructural, social and tourism development. Section four examines the changes in ownership structure, institutions, infrastructure control and foreign direct investment attraction. Also, it examines the increased interest of domestic and foreign airline to participate in Nigeria aviation sector. Last, section five is the conclusion.

\section{THE NI GERI AN AVI ATI ON I NDUSTRY - AN OVERVI EW}

\subsection{NI GERI AN HI STORI CAL DEVELOPMENT OF AI R TRANSPORT}

The development of air transport in Nigeria had been dated back to the colonial period administration in Nigeria. The first flight into Nigeria was a British Royal Air Force (RAF) fighter that landed on a polo ground in Kano in 1925. After the maiden flight into Nigeria, the RAF began yearly flight to Kano and Maiduguri from Sudan, relying solely on available intelligence reports and navigational aids on the aircraft (Ajulo, 2002).

The commercial aviation started in Nigeria when Imperial Airlines commenced regular flights between UK and Nigeria in 1935. The development of one aerodrome was enhanced in start of the Second World War. By 1940, all the airports proposed for Nigeria had been completed.

At the end of the Second World War, the British Overseas Airways Corporation operated passenger and mail services between Lagos, Port-Harcourt, Enugu, and Jos. During this period, services were largely restricted to government business. The services then also linked Nigeria with the British West African colonies (Gold Coast now Ghana and Sierra Leone).

The West African Airways Corporation (WAAC) was established on May $15^{\text {th }}$, 1946, starting commercial air transport in the West African region. The West African Airways Corporation 
(WAAC) broke up in 1957 when Ghana gained independence to form its own airline. As a result, the assets of WAAC were shared and Nigeria inherited some aircraft and landing properties which were eventually transferred to the newly formed company called the West African Airways Corporation (Nig) Limited. The new company was incorporated by the Federal Government in partnership with BOAC and Elder Dempster Limited on $23^{\text {rd }}$ August 1958, with the Certificate of Incorporation No 1740 (Filani 1978:339).

By 1961, WAAC was re-registered and renamed Nigerian Airways Limited (NAL), after the government's acquisition of the combined interest of BOAC and Elder Dempster Lines. During this period, airline operations were only within the enclave of Nigeria Airways, which had the monopoly of operating scheduled services, and a number of private companies that later obtained licenses to operate charter flights.

Before 1970, Nigeria had two airports; the 1970-74 Second National Development Plan envisaged the development and construction of seventeen modern airports with up - to date facilities (Filani, 1978:346).

\subsection{NI GERI AN AI R TRANSPORT I NSTITUTI ONS}

The Nigerian aviation industry witnessed rapid growth from the oil boom period of the early 1970's till the era of military exploitation. During the pre-military era, the industry was transformed into a multifaceted, profit driven sector of the national economy. There was tremendous growth in the number of operators, airports and passenger traffic. The industry, however, witnessed serious decline mainly due to growing cost, poor management, bad policies and unfriendly investment environment during past military administrations.

Upon the restoration of democratic ideals, genuine demonstration on the part of Government to deregulate the economy attracted investor confidence $\mathrm{n}$ the aviation sector. Until January 2007, the policymaking institution for the aviation sector in Nigeria was the Federal Ministry of Aviation. The Ministry was restructured in late 2006, for better coordination of all transportation modes through the creation of the Federal Ministry of Transportation, having segment for modal integration as land transport - road and rail, water transport - maritime and air transport - aviation. The Ministry is headed by the Minister of Transportation who is the chief minister and supported by two Ministers of State for water and air transport respectively (Report on the FEC weekly meeting, Dec 2006). 
The Federal Ministry of Transportation (Air Transport), since then, assumes the role of the most important policymaker for the country's aviation industry. The functions and responsibilities of the Ministry include:

i. Formulation and implementation of policies and programs to provide a superior aviation environment in line with the conventions of international agreement;

ii. Overall supervision and regulation of the civil aviation industry, including airport development and management, manpower development, etc;

iii. Development and management of airports;

iv. Provision of air safety and other aeronautical services in all airports within Nigeria;

v. Provision of meteorological facilities and overseeing of training in the field of aviation meteorological services.

The Ministry has 6 Departments, 3 units, 5 parastatals and a permanent Representative in Montreal, Canada. The six Departments are:

i. Department of Air Transport Management (DATM);

ii. Department of Safety and Technical Policy;

iii. Department of Accident Investigation and Prevention;

iv. Department of Planning, Research and Statistics;

v. Department of Finance and Supplies;

vi. The Department of Personnel Management.

The three units are:

i. The Legal Unit;

ii. The Press Unit;

iii. The Internal Audit Unit.

The Parastatals are:

i. The Nigeria Civil Aviation Authority (NCAA);

ii. The Federal Airports Authority of Nigeria (FAAN);

iii. The Nigerian Airspace Management Agency (NAMA);

iv. The Nigerian Meteorological Agency (NIMET);

v. The Nigeria College of Aviation Technology (NCAT);

Source: (http:www.ministryofaviationng.org) 
The Nigeria Bureau of Public Enterprise is the government institution charged with the privatization of public sector owned enterprises in Nigeria and the National Privatization Council (NCP) provides the enabling environment for the investor's participation in the privatization of government owned enterprises (Federal Government of Nigeria 2008).

In the Nigerian aviation industry, aside the government functionaries are the stakeholders that include: the airlines, aviation services, airports, manufacturers etc. Figure 1 shows the structure of the Nigerian air transport sector, its constituent parts, producers and consumers. In fact, the air transport industry in Nigeria is fast reaping the gains of globalization and deregulation.

Figure 1: Nigerian Air Transport Industry

\section{CONSUMERS}

\section{Freight}

- Transporters

- Freight forwarders

, warehouse

- Cleaning

Agent

- Third Party

Logistics

\section{Passengers}

- Business

- Educational

- Leisure

- Other

Travelers

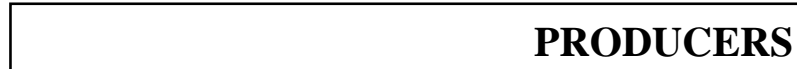

PRODUCERS

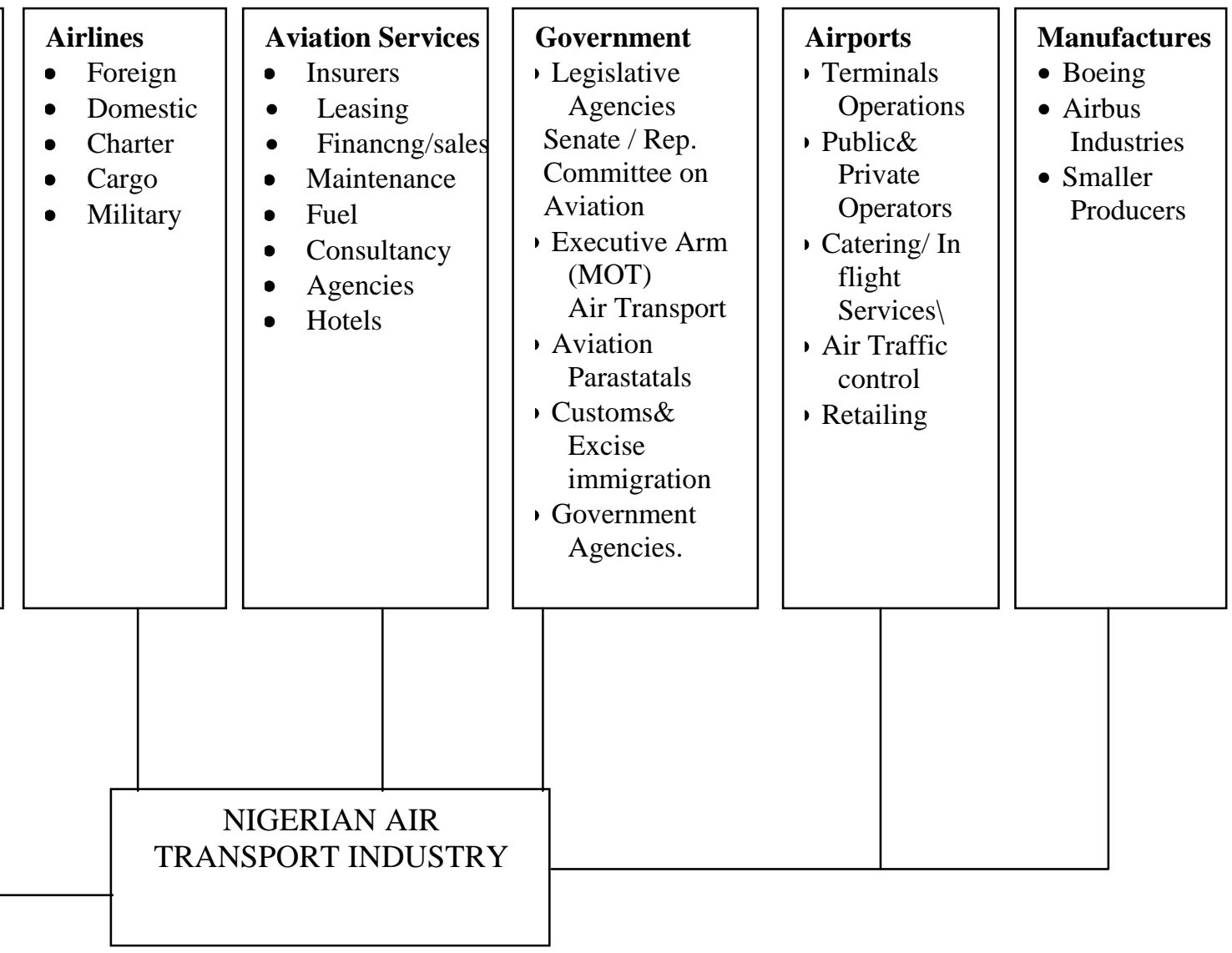




\section{DEREGULATI ON IN THE NI GERI AN AI R TRANSPORT INDUSTRY}

The major distinctive feature of globalization is deregulation. Deregulation, privatization and liberalization are seen as gains of retooling the economic system to favour expansion, economic growth, capital flight and foreign direct investment. (Page, 2005) asserts that globalization inevitably produces 'Winners and Losers' in the pursuit of business, and recognize deregulation as one of the distinctive process associated with it.

The Nigerian air transport industry has no doubt benefited from the policy innovation gains intrinsic and outside the deregulation policy framework. Few attempts have been made from mid-1980s towards commercialization and privatization in Nigeria aviation. It was first documented in the report of T.C.P.C (Technical Committee of Privatization and Commercialization), which classified the then Nigerian Airport Authority for partial commercialization in 1985, and subsequently classified NAA for full commercialization in 1989 (OECD 2006 Report on Nigeria, African Express Outlook).

However, this period characterized a blur picture in the Nigeria aviation history because of the political instability. During this period, investment in the Nigeria aviation industry is considered too risky and not viable. Passenger traffic and other activities at the airport dwindled tremendously. The industry witnessed serious decline mainly due to growing cost, poor management, bad policy and unfriendly investment environment during past military administrations.

The Yamoussoukro declaration seems the advent of a new African Civil Aviation policy adopted on $7^{\text {th }}$ October 1988. This declaration called for the liberalization and integration of air services to pave the way for the continent's to actively participate in the globalization process and regional development (Idrisu, 2004). In line with this declaration, the government policy in the late 1980s and early 1990s were directed in the direction of liberalization and limited or guided deregulation of the air transport market.

Prior to 1989, the regulation of the aviation industry as well as provision of air traffic services were carried out by the Civil Aviation Department (CAD) of the Federal Ministry of Aviation. Further to the adoption of the National Policy on Civil Aviation of 1988 by the Federal Government, the Federal Civil Aviation Authority (FCAA) was established under decree 8 of 1990 as an aviation regulatory body and took over the function of CAD. 
This period mark the advent of liberalization and deregulation of the Nigerian aviation industry. The national flag carrier, Nigeria Airways, was beset by administrative and financial difficulties (its fleet declined from 28 to 4 aircraft between 1978 and 1988 and 2 in 1999, while its debt portfolio rose to nine - figure level (Momodu, 1993 cited in Idrisu, 2004). Also some of its fleet was confiscated abroad because it could not offset debt portfolio owned abroad. To meet the growing demand for air services with the shrinking performance of Nigerian Airways, the government removed market restrictions and allowed a number of private companies to operate air transport services.

The inconsistency in policy direction afterwards, caused major flaws which acted against healthy competition and the ability to attract foreign direct investment. The Nigeria Airport Authority (NAA) which had earlier been carved out of the CAD in 1979 to manage Nigerian Airports was an example. Towards the end of 1995, the government undertook a reorganization of some government agencies in the aviation industry; as a result, the FCAA was scrapped. New Directorates of Safety Regulation and Monitoring (DSRAM) and Economic Regulatory and Monitoring (DERAM) were established in the Federal Ministry of Aviation, to replace the safety and economic regulatory function of the defunct FCAA while Air Traffic Service (ATS) and Airport Department were merged with the former NAA to form Federal Airports Authority of Nigeria (FAAN).

This re-organization of government agencies left a vacuum because of the inefficacy of the new arrangements to activate the needed competition and provide a reliable, effectual regulatory framework to stimulate competition among the new operators. In addition, because of the political instability that characterized this period, investor confidence in Nigeria aviation sector dwindled. The operators licensed to operate during this period often had their fleet phased out and depended on aged aircraft, thus experienced increasing costs, risk, erratic air service schedule, passenger delay and ineffectual service delivery. In conclusion, the military era with sterile institution and misconception of needed policy direction characterized a first but failed attempt to liberalize and deregulate the Nigerian air transport industry.

\subsection{POST MI LITARY ERA}

The restoration of democratic ideals on May $29^{\text {th }}, 1999$, was the beginning of innovation in governance. There was genuine demonstration on the part of Government to deregulate the 
economy and growing investor confidence in the nation. The stage is set for vibrant and profitable aviation sector.

There was a remarkable paradigm shift and attention of government to ideally deregulate the sectors of the economy. Aviation is one of the earmarked sectors to benefit from the dividend of democratic ideals. It was conceived to allow the country to also benefit from the deregulation experience of US in 1978 and later Europe and Australia. (Debbage, 2004) argues that deregulation in North America was also a springboard for aviation strategies later adopted in Australia and those planned for the EU.

Immediately, the government set up institutions that would oversee the privatization of the sectors of the Nigerian economy. The Bureau of Public Enterprise was charged with this responsibility. Also, the restructuring of the Aviation agencies was carried out. Indeed, it can be said that between the periods 1999 - 2007, there was a remarkable restructuring of agency and institutions for the deregulation of the aviation sector after the failed attempt during the military era.

The Department of Safety Regulation, Monitoring and Economic Regulatory (DSRAM) of Federal Ministry of Aviation was carved out into NCAA, which is the economic and technical regulator of the aviation industry. It consists on local and international legal status. NCAA was established according to the decree 49/1999, and among others, refers to the statutory responsibilities of regulation, monitoring and promoting of the safety, security and reliability of air navigation in the Nigerian Civil Aviation sub-sector in line with the International Civil Aviation Organization (ICAO) standards and recommended practices (SARPS). The Authority effectively commenced its operations on $1^{\text {st }}$ of January, 2000. This is the responsible body for setting the standards of the International Civil Aviation Organization (ICAO) activities and ensuring that states fulfill the obligations provided in the convention of International Civil Aviation.

The body, according to its conditions, requires all member states to establish a suitable state organization to be known as civil aviation authority charged with necessary powers to ensure compliance with air navigation regulations promulgated by the state. Nigeria as a signatory to the convention and desirous to maintain its ICAO membership had to fulfill this obligation. In this framework and responding to the requirements of the aviation industry 
stakeholders, the Federal Military Government, prior to its fall, enacted Decree 49 of 1999 establishing the NCAA.

Moreover, in the same period, the Act No 48 established the Nigerian Air Management Agency (NAMA) on 26 May 1999, as a body to corporate with perpetual succession and common seal. The Agency operates under Nigerian laws, rules and regulations based on the framework established in the Chicago convention, which regulates International Civil Aviation. The statutory function of the agency is to provide a safe, secure, efficient and economic air navigation service according to the international standards.

Remarkably, on 16th May, 2001, the Federal Executive Council (FEC) approved the transformation of the Department of Meteorological services of the Federal Ministry of Aviation into the Nigerian Meteorological Agency (NIMET). The bill for the establishment of NIMET was passed into law by the National Assembly in June 2003. The establishment of NIMET as an autonomous Agency, which had been elusive for nearly 20 years, remains one of the landmark achievements of advent of democratic government in Nigeria towards the deregulation of Nigeria air transport industry.

Taking into account the abovementioned, the Federal Airport Authority of Nigeria (FAAN) was established in August 1995, in order to carry out the functions of two erstwhile organizations -The Nigerian Airport Authority (NAA) and Federal Civil Aviation Authority (FCAA). The Federal Airport Authority of Nigeria (FAAN) maintains and manages the 22 Airports of the country on behalf of the Federal Government - who is the owner of these facilities. The Bureau of Public Enterprise classified FAAN for privatization in 2001. By 2007, FAAN has begun to assume a landlord model with a concessionaire, under a BOT partnership arrangement to build, operate and transfer the Muritala Mohammed Terminal II (MMA 2) after 35 years. Indeed, this is one of the dividends of deregulation.

\section{THE IMPACT OF DEREGULATION AND LIBERALIZATION IN NIGERIAN AIR TRANSPORT}

The positive impact of deregulation and liberalization is obvious in the Nigerian air transport industry. Thus, this section tends to highlight and discuss the impact of deregulation and liberalization in Nigerian air transport industry. 
One of the major advantages of deregulation in the Nigerian air transport industry is the entry of new operators, which injected fresh capital into the sector. The total amount of fund injected is estimated for about US $\$ 5$ billion in the next three years. The Boeing Company reported orders that Nigerian airline, namely Arik Air, has ordered 15 new planes with list price of $\$ 1.8$ billion. (Allafrica, 2008)

Table 1: Number of Arik Air present and ordered fleet (at March 2008).

\begin{tabular}{|c|c|c|c|}
\hline AIRCRAFT & TOTAL & ROUTE & NOTES \\
\hline Boeing 737-322 & 2 & $\begin{array}{l}\text { Domestic and } \\
\text { Regional Routes }\end{array}$ & \\
\hline Boeing 737-700 & 4 & $\begin{array}{l}\text { Domestic and } \\
\text { Regional Routes }\end{array}$ & 6 on order. \\
\hline Boeing 737-800/900 & 0 & & 17 on order. \\
\hline Boeing 777-200LR & 0 & & $\begin{array}{l}2 \text { on order (delivery } \\
2011 \text { ). }\end{array}$ \\
\hline Boeing 787-300ER & 0 & & $\begin{array}{l}3 \text { on order (delivery } \\
2011 \text { ). }\end{array}$ \\
\hline Boeing 787-9 & 0 & & $\begin{array}{l}7 \text { on order (delivery } \\
2011 \text { ). }\end{array}$ \\
\hline $\begin{array}{l}\text { Bombardier CRJ - } \\
\text { 900ER }\end{array}$ & 4 & $\begin{array}{l}\text { Domestic and } \\
\text { Regional Routes }\end{array}$ & 3 on order \\
\hline $\begin{array}{l}\text { Bombardier Dash } 8 \\
\text { Q300 }\end{array}$ & 3 & Domestic Routes & $\begin{array}{l}\text { Lease from Denim } \\
\text { Air. }\end{array}$ \\
\hline $\begin{array}{l}\text { Bombardier Dash } 8 \\
\text { Q400 }\end{array}$ & 0 & & 4 on order \\
\hline $\begin{array}{l}\text { Hawker Executive } \\
\text { Jets } 800 x \mathrm{P}\end{array}$ & 2 & & \\
\hline
\end{tabular}

SOURCE: The 2008 Arik Air Press Releases

Similarly, Virgin Nigeria has made an investment that worth over $\$ 250$ million dollars, which includes the initial equity contribution made by the investors of the establishment of Virgin Nigeria (Virgin News, 21 February 2008). In the past two years, Virgin Nigeria has built up a 
global staff of over 1,200 personnel, operating a fleet of 10 aircraft. In addition, it has recently ordered 24 Embraer aircraft as part of its expansion program.

The significant impact of deregulation in the case of air transport, freight tonnage and passenger traffic, is the increase of 54 percent and 9.4 percent per annum, respectively, during the period 2000 to 2004.

TABLE 2: SHOWING NIGERIAN AIR TRANSPORT BASIC DATA 2001-2005.

\begin{tabular}{|l|c|c|c|c|c|}
\hline $\begin{array}{l}\text { DESCRIPTION AIR } \\
\text { TRANSPORT. }\end{array}$ & 2001 & 2002 & 2003 & 2004 & 2005 \\
\hline $\begin{array}{l}\text { Loaded Freight (000 } \\
\text { tonnes) }\end{array}$ & 6.06 & 7.53 & 13.28 & 21.91 & 48.31 \\
\hline $\begin{array}{l}\text { Unloaded Freight } \\
\text { (000 tonnes) }\end{array}$ & 50.46 & 47.94 & 57.70 & 62.53 & 78.17 \\
\hline $\begin{array}{l}\text { Passengers } \\
\text { Departing } \\
\text { (Numbers) }\end{array}$ & $2,633,173$ & $3,074,893$ & $3,607,190$ & $4,124,027$ & $4,207,503$ \\
\hline $\begin{array}{l}\text { Transiting } \\
\text { passengers(Number) }\end{array}$ & 139,503 & 91,944 & 166,581 & 57,480 & 215,173 \\
\hline $\begin{array}{l}\text { Arriving passengers } \\
\text { (Number) }\end{array}$ & $2,590,982$ & $2,978,625$ & $3,526,398$ & $4,016,061$ & $4,104,303$ \\
\hline $\begin{array}{l}\text { Aircraft } \\
\text { (Number) }\end{array}$ & 62,572 & 70,613 & 85,764 & 99,385 & 92,830 \\
\hline Aircraft Take Off & 62,506 & 70,050 & 85,731 & 99,118 & $93,006$. \\
\hline
\end{tabular}

SOURCE: The 2006 Annual Report of Federal Ministry of Aviation, Nigeria

The statistics from Federal Ministry of Aviation in Table 2 substantiate the statistics from OECD 2006, African Economic Outlook report on Nigeria. The route development in both domestic and international network has been so far encouraged. Major airlines such as Arik Airline, Virgin Nigeria, Bellview and Aero contractors have expanded their regional network and regarding International routes they are now linked with countries such as USA, UK and other African countries. This is a significant development step because it would further attract more investments portfolio into the operation and expansion of these airlines. The 
Table 3 shows the Virgin Nigeria fleet as at March 2008 and number of orders from the major aircraft manufacturers and air leasing company.

TABLE 3: Showing Virgin Nigeria Airways Fleet (At March 2008).

\begin{tabular}{|c|c|c|c|c|}
\hline AIRCRAFT & TOTAL & $\begin{array}{l}\text { PASSENGERS } \\
\text { (BUSINESS/ECONOMY) }\end{array}$ & ROUTE & NOTES \\
\hline $\begin{array}{l}\text { Boeing 737- } \\
300\end{array}$ & 5 & IL6(16/100) & $\begin{array}{l}\text { Short and } \\
\text { Medium } \\
\text { Hall route }\end{array}$ & $\begin{array}{ll}\text { Leased } & \text { from } \\
\text { GECAS. } & \end{array}$ \\
\hline $\begin{array}{l}\text { Boeing 767- } \\
300\end{array}$ & 2 & $213(25 / 188)$ & $\begin{array}{l}\text { Medium } \\
\text { and Long } \\
\text { haul route }\end{array}$ & $\begin{array}{l}\text { Leased from } \\
\text { Latcharter. }\end{array}$ \\
\hline Embraer 170 & (7orders) & $67(7 / 60)$ & $\begin{array}{l}\text { Short haul } \\
\text { Region } \\
\text { service }\end{array}$ & $\begin{array}{l}\text { Entry into } \\
\text { service:2008 } \\
\text { Deliveries:2008- } \\
2011\end{array}$ \\
\hline Embraer 190 & $\begin{array}{l}\text { (3orders) } \\
\text { (6options) }\end{array}$ & $(12 / 84)$ & $\begin{array}{l}\text { Short haul } \\
\text { Regional } \\
\text { service }\end{array}$ & $\begin{array}{l}\text { Entry into } \\
\text { service: } 2008 \\
\text { Deliveries } 2008 \text { - } \\
2011 \\
8 \quad \text { purchase } \\
\text { right. }\end{array}$ \\
\hline Fokker & 2 & $50(0 / 50)$ & $\begin{array}{l}\text { Short haul } \\
\text { Domestic } \\
\text { services. }\end{array}$ & $\begin{array}{ll}\text { Leased from } \\
\text { Denim Air }\end{array}$ \\
\hline
\end{tabular}

SOURCE: The 2008 Virgin Nigeria Press Releases

The deregulation has provoked spatial effect similarly to the spatial structure in air travel that had emerged in the USA. Thus, creating hubs, a cost solution for airlines is given (Chou, 1993; Shaw, 1993; O'kelly, 1983) (cited in Page, 2005). Such spatial patterns are beginning to emerge in Nigerian airspace leading to formulation of hub and spoke airline 
operation structure as to strategies for organizing airlines operation. Thus, a geographical concentration of airline hubs in few Nigerian cities was created.

This is laid down in the deregulation regime and the position the aviation sector in proper perspective of financial solvency. And to avert further air mishap in the country due to the incessant mishap between the periods of 2002-2006, which had provoked the lost of many lives, the Federal Government of Nigeria, through its supervisory agency requests the operating airlines to recapitalize. The policy actually would help to phase out weak airlines and to adopt strategic planning options as the acquisition in the case of NICON airways purchases equity of EAS Airlines and Virgin Nigeria purchasing equity in Nigerian Airways. Ancillary activities involve development in different options among airline operators in Nigeria. Some airlines now offer scheduled flights to tourism destinations in Nigeria. The Wings Aviation that operates daily flights to Obudu Cattle Ranch, a foremost tourist site in southern part of Nigeria, is an example.

The following airlines were approved by the NCAA after the recapitalization exercise on the $1^{\text {st }}$ of May, 2007:

1. Aero contractors - http//www. flyaero.com

2. Afrijet Airlines - http//www.afrijet.com

3. Allied Airlines - http//www.alliedaircargo.com

4. Associated Airlines - http//www.associationaviationlimited.com

5. Bellview Airline - http//www.flybellviewair.com

6. Chanchangi Airlines - http//www.chanchngi.com

7. Dornier Aviation Nigeria Limited - [no website]

8. NICON Airways - http//www.niconairways.com

9. IRS Airlines - http//www.irs-airlines.com or http://www.irsairlines.net

10. Overland Airways - http://www.overland.aero

11. Air Midwest - [New entrant]

12. Arik Air - http://www.arikair.com

13. Virgin Nigeria - http//www.virginnigeria.com

The following airlines didn't meet the requirements:

1. ADC - http://www.adcairlines.com

2. Sosoliso Airlines - http://www.sosolisoairline.com

3. Fresh Airlines - http//www.freshairlines.com 

4. Albarka Airlines
5. Dasab Airlines
6. Space World Airlines.

The fate of some other charter companies still unknown:

1. Kabo Air - http://www.kaboair.com

2. Wings Aviation

3. King Airlines - http://www.kingairlines

It is worth mentioning that the impact of deregulation of air transport in Nigeria caused the establishment of MMA 2, which is a perfect example of Public Private Partnership. The new terminal building in Muritala Mohammed Airport which can process over five million passengers per annum, far in excess of the current volume. The MMA 2 was an arrangement between the $\mathrm{Bi}$ - Courtney on Build, Operate and Transfer (BOT) and the government. The domestic passenger volume for the Lagos airport reached 1.6 million (Odunlami, 2008). The new terminal building in Muritala Mohammed Airport can process over five million passengers per annum, far in excess of the current volume.

The investment in hanger operations by one of the operating airlines in Nigeria is a significant and noteworthy advantage of deregulation in Nigerian air transport Industry. The Afrijet Airlines invested in the construction of private hanger operation in order to be used by the domestic and foreign airline operators in Nigeria. The investment amount was above US \$1.5 million and has significantly contributed to the airline operations in Nigeria.

In addition to the positive impact of deregulation, the Nigerian Civil Aviation Authority gave license to small operators outside the regular schedule service in the domestic and regional operations, to private companies with many fixed wings aircraft and helicopters servicing the oil fields as well as an increasing number of corporate and private aircraft (Idrisu, 2004). He went further to stress that some multinational oil companies have constructed their own airport to enhance the movement of both materials and workers in their onshore and offshore operations. An example is the Osubi Airport in Warri, Nigeria, owned and managed by Shell Petroleum Development Company. 


\section{ONWERSHIP AND INSTITUTIONAL CHANGES IN NIGERIAN AIR TRANSPORT}

It is important to note the ownership structure, institutional changes in Nigerian air transport, infrastructure control, foreign direct investment, increased interest of domestic and foreign airline participation in Nigerian aviation industry.

The last Administration, 1999 to 2007, made an effort to liberalize and deregulate the Nigerian economy. Some institutions were established to monitor the full liberalization of the economy. The Bureau of Public Enterprise and the National Council of Privatization were established to be charged with this responsibility. The Nigeria aviation industry was marked as one of the critical sectors for ownership and institutional changes, as well as to create open access for infrastructural development. In year 2000, the Nigerian Airways were noted for merger, before it was finally merged in year 2004. The partnership investor was Virgin Atlantic who acquired the $49 \%$ of the airline and the Nigeria investor of different corporate sub-sector acquired the $51 \%$ in the new deal. The merger gave birth to Virgin Nigeria which started operation on the $24^{\text {th }}$ September, 2004.

The NCAA was created from the Directorates of Safety Regulation and Monitoring of the Federal Ministry of Aviation. This was done to conform to ICAO recommendation, as well as to provide a framework for the deregulation and liberalization agenda of the Federal Government of Nigeria. Also, the NAMA, the Nigerian Airspace Management Authority (NAMA), was responsible for the provision of seamless Air Traffic Management Services for the local and International airline operators. The Nigerian Meteorological Agency (NIMET) bill was signed into law by the National Assembly in June 2003, full autonomy granted to provide accuracy, timely weather/climatic data to enhance airline operations, maritime navigation and urban development.

The private sector involvement in the Airport development in Nigeria was a reality. In 2002, the MMA 2 was conceded to Bi-Courtney Ltd; it was the first PPP project for Airport development in the history of Nigeria. Part of the Muritala Mohammed terminal was leased to an investor for a period of thirty five years. This arrangement led to the massive investment of Bi-Courtney in the airport terminal development, the construction of four -star hotel and a conference hall close to the new terminal. (Graham, 2001) (Cited in Page, 2005:280) says the "Airport are an essential part of the air transport system. They provide the entire infrastructure needed to enable passengers and freight to transfer from surface to 
air modes of transport and to allow airlines to take off and land. The basic infrastructure consists of runways, taxiways, apron space, gates, passenger and freight terminals and ground transport interchanges".

The institutional and ownership changes attracted foreign direct investment. The total estimated foreign direct investment portfolio in the sector both now and in the next five years is estimated for about US $\$ 10$ billion. This has been made possible by the institutional re-arrangement to facilitate injection of new funds into the sector. Also increased foreign airline participation, such as Delta Airlines, Qatar Airways, South African Airways, Air France, Turkish Airlines etc enhanced the air transport sector in Nigeria.

\section{CONCLUSI ONS}

The impact of deregulation and liberalization in the Nigerian air transport industry is positive. The sector is growing continuously, expanding market and investment opportunities and an aura of investment opportunities. In this way, it will significantly contribute to the enhancement of the Nigerian economic development.

The sector, since deregulation, has attracted new entrants, increased foreign direct investment, increased domestic and foreign airline participation, private sector participation in airports and infrastructural development, increased investment portfolio in airline business etc.

Also, the effect of deregulation and liberalization in the Nigerian aviation industry has provoked a spatial pattern and structure. Formulation of hub and spoke structure of airline operations is obvious in airline operations in Nigeria. The geographical concentration of airline operations in Muritala Mohammed international airport, Lagos and Nnamdi Azikiwe international airport, Abuja as the operational hubs for most airlines of the country for national, regional and international flights. This is a remarkable effect of deregulation and liberalization of the Nigerian aviation Industry.

Lastly, the institutional framework and operational capacity have been enhanced. The policy formulation framework has been strengthened towards innovations and competitive régime, thereby inducing effectiveness, efficiency and reliability in the operations and management of airline business in Nigeria. 


\section{REFERENCES}

- Adeniji K (2000), Transport Challenges in Nigeria in the Next two decades, Nigeria Institute of Social and Economic Research (NISER) Transport Studies Unit.

- Ajulo S.B. (2002), Aviation Handbook, Volume 1, Vantage Publishers Limited, Ibadan, Nigeria.

- Allafrica (2008), Airlines in Ambitious Fleet Modernisation Plans, Available from: http//www. allafrica.com/stories/200801141788.html (accessed on 18/6/2008)

- ATAG (2000), The Economic Benefits of Air Transport, Brussels: ATAG.

- Debbage, K. (2004), Airlines, airports and International aviation, in L. Pender and R. Sharplry (eds.) The Management of Tourism, London: Sage.

- FEC (2006), Report on Federal Executive Council weekly meetings, Abuja, Nigeria, Dec. 2006. Federal Ministry of Aviation (2006) The 2006 Annual Report of Federal Ministry of Aviation, Nigeria from: http//www.ministryofaviation.org/annual report (accessed 24/3/08)

- Filani M.O. (1978), Air Transport, In: J.S Oguntiyinbo (ed). Geography of Nigeria, Ibadan, Heinemann

- Idrisu D.I (2004), Air Transport Liberalization and Open Skies Agreements in Africa The Regulatory and Commercial Implication for Nigeria. Unpublished PhD thesis, St. Clements University

- Janelle,D. and Beuthe, M.(1997), Globalization and research issues in transportation, Journal of Transport Geography, 5(3): 199 - 206.

- Page S .J (2005), Transport and Tourism, Global Perspectives (2 ${ }^{\text {nd }}$ edition), Harlow: Pearson Education.

- Odunlami N (2008), Thoughts on MMA2, The News, Vol 30, No 15,April 21,2008

- OECD Report (2006), African Economic Outlook on Nigeria, Organization for Economic Cooperation and Development (OECD), Paris.

- Rodrigue P.T., Comtois, C. and Slack B. (2006), The Geography of Transportation Systems, Oxford: Routledge.

- Virgin Nigeria (2008), Virgin Nigeria's Nigerian Shareholders Statement on the Relocation order by the Federal Government of Nigeria, In: VNA Press Release, 21 February 2008.

- Virgin Nigeria (2008), Virgin Nigeria's Airways Press Releases, Virgin Nigeria 2008 online Reports www.virginnigeria.com (accessed 19/6/2008)

- Arik Air (2008), Arik Air Airways Press Releases, Arik Air 2008 online Report, www.arikair.com (accessed 19/6/2008). 
- Federal Government of Nigeria (2008), Privatization and liberalization of Government enterprise , available from: http://www.nigeria.gov.ng/privatisation (accessed 20/3/2008)

- NCAA (2008), Number of Airline after recapitalization, available from: http:// www.ncaa.gov.ng/airline/recap (accessed 8/4/2008). 